\title{
Nutritive evaluation, metabolisable energy and digestible amino acid contents of different indigenous feedstuff for Nile tilapia (Oreochromis niloticus)
}

\author{
F. Bibi ${ }^{a *}$ (D), S. N. Qaisrani ${ }^{b}$ (D) and M. Akhtar ${ }^{a}$ \\ ${ }^{a}$ Faculty of Veterinary Sciences, Bahauddin Zakariya University, Multan, Pakistan \\ ${ }^{b}$ Department of Animal Nutrition, University of Veterinary and Animal Sciences, Lahore, Pakistan \\ *e-mail: fehmeeda.bibi@bzu.edu.pk
}

Received: November 6, 2018 - Accepted: March 6, 2019 - Distributed: November 30, 2020

\begin{abstract}
Three trials were executed to examine the nutritive profile, metabolisable energy and digestible amino acid (AA) contents of four indigenous feed ingredients including wheat (W), wheat middling (WM), canola meal (CM) and rapeseed meal (RSM) in Nile tilapia. Three samples of each test ingredient were collected from three different locations of Multan (MUL) and Sukkar (SKR), of Pakistan. The collected three samples were pooled thereafter to make a homogenous/ representative sample of each test ingredient from a particular study site. Nutrients composition, AA and energy digestibility of these indigenous ingredients were evaluated by using laboratory analyses and fish studies. Proximate analysis indicated variations in some of the nutrients due to location $(p<0.05)$. Differences were also observed in some AA including arginine, lysine, serine, cysteine, glutamic and aspartic acids, histidine, valine and glycine contents of these ingredients $(p<0.05)$. Digestibility of leucine, glycine and glutamic acid was higher $(p<0.05)$ in RSM from MUL. Among W samples from MUL, AA digestibility for lysine, threonine, and aspartic acid was higher $(p<0.05)$. Crude protein, arginine, alanine, serine, and aspartic acid had higher digestibility $(p<0.05)$, whereas digestibility was lower $(p<0.05)$ for threonine, valine and tyrosine in RSM from MUL. Metaboliseable energy contents did not differ among W, WM, CM and RSM regarding their origin $(p>0.05)$. The results indicated that nutritional profiles and their digestibility indices vary with the location for Nile tilapia.
\end{abstract}

Keywords: Indigenous ingredients, amino acid, energy, digestibility, Nile tilapia.

\section{Avaliação nutricional, energia metabolizável e conteúdo de aminoácidos digestíveis de diferentes alimentos indígenas para tilápia do Nilo (Oreochromis niloticus)}

\begin{abstract}
Resumo
Três experimentos foram executados para examinar o perfil nutritivo, a energia metabolizável e o conteúdo de aminoácidos digestíveis (AA) de quatro ingredientes alimentícios, incluindo trigo (W), farelo de trigo (WM), farelo de canola (CM) e farelo de colza (RSM) em tilápia do Nilo. Três amostras de cada ingrediente do teste foram coletadas de dois locais diferentes (Multan (MUL) e Sukkar (SKR), do Paquistão) e assim agrupadas. A composição nutricional, AA e digestibilidade energética desses ingredientes indígenas foram avaliadas por meio de análises laboratoriais e estudos de peixes. A análise imediata indicou variações $(p<0,05)$ em alguns dos nutrientes devido à localização. Variações $(\mathrm{p}<0,05)$ também foram observadas em alguns teores de AA desses ingredientes. A digestibilidade da leucina, glicina e ácido glutâmico foi maior ( $p<0,05)$ em RSM de MUL. Entre as amostras de W da MUL, a digestibilidade de AA para Lys, Thr e Asp foi maior $(\mathrm{p}<0,05)$. Proteína Crud, arginina, alanina, serina e ácido aspártico apresentaram maior digestibilidade $(p<0,05)$, e menor $(p<0,05)$ para treonina, valina e tirosina em MRS. Nenhuma diferença $(p>0,05)$ relacionada a energia metabolizável foi observada entre esses ingredientes em relação à sua origem. Os resultados indicaram que os perfis nutricionais e sua digestibilidade variam com a localização.
\end{abstract}

Palavras-chave: ingredientes indígenas, aminoácidos, energia, digestibilidade, tilápia do Nilo.

\section{Introduction}

In aquaculture production, feed cost accounts for about 50 to $80 \%$ of the total production cost (FAO, 2017), where crude protein and energy being the most expensive ones.
The major energy sources used in fish feed are cereal grains including corn that contribute up to $50 \%$ of the fish diets (Marković et al., 2016). The higher inclusion 
level of corn in fish diets is not economical because of its higher production cost with seasonal fluctuation, less availability in shortage periods (Dec-Jan and May-June) and more demand by the feed industry (NARC, 2017). Additionally, corn is also used for human food as corn flour, corn oil and also in silage production for animals. For least cost feed formulation, therefore, there is a dire need of alternative, cheaper and readily available energy sources including wheat, sorghum, wheat middling and barley for aquaculture feed.

The use of highly digestible protein sources including fish, shrimp and soybean meals in aquaculture feed may lead to a higher feed cost. There is a tremendous pressure on nutritionists, therefore, to find out substitute of the mentioned protein sources in aquaculture production. The possible low-cost alternative energy and protein sources of corn and SBM includes wheat (W), wheat middling (WM), canola meal (CM) and rapeseed meal (RSM) in fish diets (Toghyani et al., 2015). Canola is an improved variety of rapeseed with lower concentration of erucic acid $(<2 \%$ in oil $)$ and glucosinolates $(<30 \mu \mathrm{mol} / \mathrm{g})$ in the defatted meal (Maison and Stein, 2014). This improved variety is called "double zero" and "canola" in Europe and Australia, and North America, respectively (Newkirk, 2009). High fiber content (12\%) in CM decreases energy and protein digestibility resulting in a lower AMEn (Khajali and Slominski, 2012). Nutritional values of different cereal grains are determined primarily by chemical composition (Fairbairn et al., 1999), and these results may be applied to forecast nutritional profile precisely. The nutritional profile of an ingredient is interrelated with several factors including variety, agronomic practices, geographical locations, environmental circumstances, harvesting conditions and processing of the seed and meal (Daun et al., 2011). Nutritional contents, however, differ between various ingredients, with different digestibility and availability to aquatic animals. Data regarding the nutritional profile including digestible energy and other essential nutrients including protein as well as AA is essential for precise feed formulation and to control the aquaculture wastes (Zhou et al., 2004; Liu et al., 2009). Measuring the total, as well as bioavailable protein and AA, are important to assess the quality of an ingredient. The bioavailable AA is described as the amount of AA that will be digested, absorbed and used in the animal or birds body (Ravindran and Bryden, 1999).

There is a scarcity of published data regarding the apparent digestibility coefficients of amino acids and metabolisable energy of indigenous protein and energy sources in tilapia fish. The objectives of the study were, therefore, to evaluate the nutritive profiles, especially gross energy, protein and AA contents, apparent metabolisable energy (AME), and apparent digestibility of protein and AA of indigenous wheat, wheat middling, canola meal and rapeseed meal from different origin in tilapia fish.

\section{Materials and Methods}

In total, 3 samples of each indigenous energy (wheat (W) and wheat middling (WM)) and protein source (canola meal (CM) and rapeseed meal (RSM)), were collected from two diverse topographical sites i.e. Multan (MUL), Punjab and Sukkur (SKR), Sindh of Pakistan and pooled thereafter.

\subsection{Fish stock for AME of indigenous energy sources}

A total of 300 sex-reversed Nile tilapia (Oreochromis niloticus) of about $5 \mathrm{~g}$ body weight were reared on a commercial diet for four weeks (28 days) with feed at $10 \%$ of their body weight. The fish were maintained in 15 cylindrical fiber glass tanks ( 20 fish in each) with $450 \mathrm{~L}$ volume containing individual aeration system, water supply and central drainage with $100 \%$ water renewal of at least two times per day. Tanks were used as a flow-through metabolic chambers. To minimize environmental fluctuation, tanks were placed in an indoor room and the water temperature was maintained at 26 to $28^{\circ} \mathrm{C}$ by using water submerged heaters. The $\mathrm{pH}$ (7.2-8.5) and dissolved oxygen (DO), maintained above $5.0 \mathrm{mg} \mathrm{L}-1$, in water were measured daily through portable $\mathrm{pH}$ meter (STARTER 300pH portable, Ohaus company) and DO meter (STARTER 300D portable, Ohaus company).

\subsection{Diets and excreta collection}

For four weeks, four experimental diets of W and WM from two different origins, with one reference diet were provided to fish (Table 1). Each diet was randomly assigned to three tanks with $20 \mathrm{fish} /$ tank in a completely randomized design. All the experimental diets were offered in mash for seven days as an adaptation period for fish. After an adaptation period, fish were off feed for $24 \mathrm{hrs}$ and fecal material from each tank was completely washed. The fecal samples were collected on daily basis in a $200 \mathrm{~mL}$ capacity plastic container and immediately stored. At the end of the collection period, the samples from experimental diets and excreta were analysed for $\mathrm{DM}$ and gross energy (GE) contents with the help of a bomb calorimeter. The determination of metabolisable energy of feedstuff was carried out using AOAC (2000).

\subsection{Fish stock for amino acid digestibility of indigenous energy sources}

A total of 300 sex-reversed tilapia (Oreochromis niloticus) individuals of about $33 \mathrm{gm}$ on an average weight were randomly distributed among 15 tanks containing 20 fish each on a commercial diet for three days. The physical and chemical properties of water were same as mentioned above in section 2.1 of the manuscript.

\subsection{Diets and excreta collection}

The experimental diets (Table 2), comprising of $\mathrm{W}$ and WM from two different origins, and a protein-free diets were offered to fishes. All the diets were randomly assigned to 15 tanks with three replicates of each. After an adaptation period of 3-days, the fishes were fasted 
for 24 hrs and randomly assigned to experimental and a protein-free diet. The experimental diets were provided at 5\% live weight to all experimental groups three times daily with equal intervals for 14 days.

The fecal samples were collected on daily basis in plastic bottles. The collected fecal samples, of each experimental unit comprising of 20 fish, were grouped into a plastic container of $200 \mathrm{~mL}$. All the collected samples were stored in air tight containers at $-4{ }^{\circ} \mathrm{C}$ for laboratory analysis.

\subsection{Fish stock for protein and amino acid digestibility of indigenous protein sources}

In this trial, 20 fish were maintained in each of the 15 cylindrical fiberglass tanks with $450 \mathrm{~L}$ capacity and containing individual aeration system, water supply, and bottom outflow. Tanks were used as a flow-through metabolic chambers.

\subsection{Diet and excreta collection}

Four diets of indigenous protein sources (Table 3) comprising of RSM and CM of two different origins, and one reference protein-free diet were formulated. Chromium oxide, an indigestible marker, was used in all the diets with $1 \%$ inclusion level. The diets were allocated to tanks, fecal samples were collected and stored as described above in section 2.4 of the manuscript

\subsection{Proximate analysis}

All chemical analyses of the ingredients, feed and excreta samples were done in duplicate. Dry matter, crude fiber, ether extract, ash and energy (bomb calorimetry) were evaluated according to the procedures described in AOAC (2000). Kjeldhal or semi-micro Kjeldhal method (AOAC 2000) was used for nitrogen content, and CP contents were determined by multiplying nitrogen with 6.25 . Chromic

Table 1. Composition of the reference and experimental diets for apparent metabolisable energy measurements in tilapia.

\begin{tabular}{lccccc}
\hline Ingredients (\%) & RD & W (MUL) & W (SKR) & WM (MUL) & WM (SKR) \\
\hline SBM & 60.0 & 39.0 & 39.0 & 39.0 & 39.0 \\
Corn & 28.0 & 19.0 & 19.0 & 19.0 & 19.0 \\
Wheat & 0.00 & 30.0 & 30.0 & 0.00 & 0.00 \\
Wheat Middling & 0.00 & 0.00 & 0.00 & 30.0 & 30.0 \\
Oil & 10.0 & 10.0 & 10.0 & 10.0 & 10.0 \\
Premix & 1.00 & 1.00 & 1.00 & 1.00 & 1.00 \\
DCP & 1.00 & 1.00 & 1.00 & 1.00 & 1.00 \\
Total & 100.00 & 100.00 & 100.00 & 100.00 & 100.00 \\
\hline
\end{tabular}

RD: reference diet; W: wheat; MUL: Multan; SKR: Sukkur; WM: wheat middling; SMB: soybean meal; DCP: di-calcium phosphate.

Table 2. Dietary ingredients and calculated nutrient composition for protein and AA digestibility in tilapia.

\begin{tabular}{lccccc}
\hline Ingredients (\%) & RD & W (MUL) & W (SKR) & WM (MUL) & WM (SKR) \\
\hline SBM & 55.5 & 36.39 & 36.39 & 36.39 & 36.39 \\
Corn & 35.0 & 24.1 & 24.1 & 24.1 & 24.1 \\
Wheat & 0.00 & 30.0 & 30.0 & 00.0 & 0.00 \\
Wheat Middling & 0.00 & 0.00 & 0.00 & 30.00 & 30.0 \\
Oil & 8.00 & 8.00 & 8.00 & 8.00 & 8.00 \\
Choline & 0.50 & 0.50 & 0.50 & 0.50 & 0.50 \\
Salt & 0.01 & 0.01 & 0.01 & 0.01 & 0.01 \\
Premix & 1.00 & 1.00 & 1.00 & 1.00 & 1.00 \\
Total & 100.00 & 100.00 & 100.00 & 100.00 & 100.00
\end{tabular}

RD: reference diet; W: wheat; MUL: Multan; SKR: Sukkur; WM: wheat middling; SMB: soybean meal.

Table 3. Dietary ingredients and calculated nutrient composition for protein and AA digestibility in tilapia.

\begin{tabular}{lccccc}
\hline Ingredients (\%) & RD & CM (MUL) & CM (SKR) & RSM (MUL) & RSM (SKR) \\
\hline SBM & 55.5 & 36.39 & 36.39 & 36.39 & 36.39 \\
Corn & 34.9 & 24.1 & 24.1 & 24.1 & 24.1 \\
Wheat & 0.00 & 30.0 & 30.0 & 00.0 & 0.00 \\
Wheat Middling & 0.00 & 0.00 & 0.00 & 30.00 & 30.0 \\
Oil & 8.00 & 8.00 & 8.00 & 8.00 & 8.00 \\
Choline & 0.50 & 0.50 & 0.50 & 0.50 & 0.50 \\
Salt & 0.01 & 0.01 & 0.01 & 0.01 & 0.01 \\
Premix & 1.00 & 1.00 & 1.00 & 1.00 & 1.00 \\
Total & 100.00 & 100.00 & 100.00 & 100.00 & 100.00 \\
\hline
\end{tabular}

RD: reference diet; MUL: Multan; SKR: Sukkur; SMB: soybean meal. 
oxide was evaluated by the Scott (1978) method. Amino acids contents were analyzed following acid hydrolysis using an AA analyzer (Biochrom 30+, Biochrom Limited. Cambridge, UK).

\subsection{Digestibility measurements}

The apparent digestibility coefficients (ADCs) of energy, protein and AA for the test ingredients and diets were calculated as described by Cho and Slinger (1979):

$$
\begin{aligned}
& A D C=100 \times\left[1-(F / D) \times\left(D_{i} / F_{i}\right)\right] \\
& A D C_{1}=\left[A D C_{T}-\left(0.7 \times A D C_{R}\right)\right] / 0.3
\end{aligned}
$$

Where, $\mathrm{D}=\%$ nutrient or energy of a diet; $\mathrm{F}=\%$ nutrient or energy of feces; $\mathrm{Di}=\%$ marker $\left(\mathrm{Cr}_{2} \mathrm{O}_{3}\right)$ in the diet; $\mathrm{F}_{\mathrm{i}}=\%$ marker $\left(\mathrm{Cr}_{2} \mathrm{O}_{3}\right)$ in the feces, $\mathrm{ADCT}=\%$ apparent digestibility coefficient of protein, amino acids or energy in the test diet; ADCR = apparent digestibility coefficient of nutrient or energy in the reference diet; $\mathrm{I}=$ test ingredient under investigation.

\subsection{Data analysis}

The data were analyzed statistically by ANOVA using PROC MIXED procedure of SAS (version 9.1, SAS Institute, 1985). Differences were considered significant at $P<0.05$ and the significant differences between the means were separated by least significant difference test.

\section{Results}

\subsection{Proximate analysis}

The findings of proximate analysis for W, WM, CM, and RSM are shown in Table 4. There were significant variances between CP contents of energy sources (W and WM). Crude protein contents were significantly higher in $\mathrm{W}$ $(p=0.026)$ and WM $(p=0.036)$ from MUL than that from SKR. Similarly, significant variations were observed in ash contents of energy contents. Ash contents were significantly higher in SKR W $(p=0.01)$ and MUL WM $(p=0.01)$. Among protein sources, SKR CM $(p=0.042)$ and RSM $(p=0.023)$ has significantly greater DM compared with that from MUL. Between protein sources, CP content of CM from SKR was significantly greater $(p=0.036)$ than those from MUL. Moreover, ash contents of protein sources were statistically greater in MUL than from SKR $(p<$ $0.05)$. Canola meal $(p=0.021)$ and $\operatorname{RSM}(p=0.026)$ from MUL had significantly greater ash contents compared with those from SKR. The GE contents of indigenous energy and protein sources were not affected by difference in origin except for CM. Gross energy contents of CM was found significantly greater $(p=0.022)$ in SKR compared with that from MUL.

\subsection{Total amino acid contents of indigenous energy sources}

The results of total amino acid contents of indigenous energy sources (W and WM) are summarized in Table 5. Among the essential amino acids (EAAs), Arg ( $p=$ $0.031)$ and Lys $(p=0.021)$ contents were significantly higher in W from SKR compared with that from MUL. Similarly, among non-essential amino acids (NEAAs) in $\mathrm{W}$, Cys $(p=0.015)$, Glu $(p=0.030)$ and Asp $(p=0.012)$ was found significantly higher, whereas $\operatorname{Ser}(p=0.04)$ contents were significantly lower in SKR that from MUL. Likewise, in WM from different origins, among different EAAs, Arg $(p=0.027)$, His $(p=0.033)$ and valine $(p=$ 0.020 ) were found significantly higher in MUL compared with SKR. All other EAAs were statistically the same in two different origins of WM. Among NEAAs in WM, Gly $(p=0.017)$, Ser $(p=0.036)$ and Glu $(p=0.010)$ were significantly higher in MUL samples compared with those from SKR.

\subsection{Digestible CP and AA contents of indigenous energy sources}

The results of protein and amino acids digestibility of indigenous energy sources are shown in Table 6. Digestibility of CP was significantly influenced by the origin $(p<0.05)$ of the ingredients in WM. Wheat middling from MUL $(p=0.031)$ had a higher digestibility of CP compared with that from SKR. Wheat from MUL showed a significantly greater digestibility of Lys $(p=0.033)$ and $\operatorname{Thr}(p=0.010)$ compared with those from SKR among essential AA.

Table 4. Proximate analysis (\%) and gross energy contents $(\mathrm{Kcal} / \mathrm{kg})$ of the indigenous protein and energy sources for fish

\begin{tabular}{|c|c|c|c|c|c|c|c|c|c|c|c|c|c|c|c|c|}
\hline \multirow[b]{2}{*}{ Item $^{1}$} & \multicolumn{4}{|c|}{ Canola Meal } & \multicolumn{4}{|c|}{ Rapeseed Meal } & \multicolumn{5}{|c|}{ Wheat } & \multicolumn{3}{|c|}{ Wheat Middling } \\
\hline & $\stackrel{3}{\Sigma}$ & $\frac{\widetilde{a}}{\mathfrak{n}}$ & 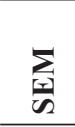 & 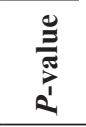 & $\stackrel{\Xi}{\Sigma}$ & $\frac{\sigma}{\sigma}$ & $\sum_{\substack{\mathbf{s} \\
\text { s }}}$ & 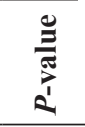 & $\stackrel{3}{\Sigma}$ & $\frac{\mathscr{a}}{\sim}$ & 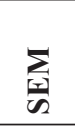 & 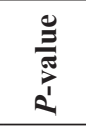 & $\stackrel{3}{\Sigma}$ & $\frac{\sigma}{\sim}$ & $\sum_{\substack{\infty \\
\infty}}$ & $\begin{array}{l}\stackrel{0}{\Xi} \\
\stackrel{0}{J} \\
2 \\
2\end{array}$ \\
\hline $\mathrm{DM}$ & 89.0 & 90.1 & 0.3 & 0.042 & 89.1 & 90.7 & 0.2 & 0.023 & 92.3 & 92.4 & 0.21 & 0.24 & 92.1 & 92.0 & 0.11 & 0.65 \\
\hline $\mathrm{CF}$ & 12.2 & 11.7 & 0.8 & 0.68 & 11.9 & 12.6 & 0.4 & 0.22 & 3.0 & 3.1 & 0.08 & 0.43 & 3.2 & 3.3 & 0.07 & 0.48 \\
\hline $\mathrm{CP}$ & 35.2 & 36.8 & 0.5 & 0.036 & 36.4 & 37.2 & 1.1 & 0.25 & 11.3 & 10.1 & 0.11 & 0.026 & 17.3 & 16.4 & 0.22 & 0.036 \\
\hline $\mathrm{EE}$ & 2.4 & 3.1 & 0.7 & 0.24 & 1.6 & 1.4 & 0.5 & 0.39 & 5.3 & 5.4 & 0.12 & 0.64 & 9.3 & 9.2 & 0.11 & 0.61 \\
\hline Ash & 6.9 & 5.8 & 0.4 & 0.021 & 9.1 & 8.2 & 0.2 & 0.026 & 1.71 & 2.21 & 0.13 & 0.01 & 6.6 & 5.4 & 0.19 & 0.01 \\
\hline GE & 4100 & 4250 & 15.6 & 0.022 & 4210 & 4260 & 20.8 & 0.171 & 4179 & 4190 & 12.4 & 0.36 & 4390 & 4430 & 20.3 & 0.37 \\
\hline
\end{tabular}
diet.

${ }^{1}$ DM: Dry matter; CF: Crude fiber; CP: Crude protein; EE: Ether extract; GE: Gross energy. Results described as means of triple observation. MUL: Multan; SKR: Sukkur; SEM: standard error of mean. 
The digestibility of only Asp was significantly greater $(p=0.04)$ in MUL compared with that from SKR, among NEAAs. Similarly, in WM, among EAAs, digestibility of valine $(p=0.01)$ and $\mathrm{Thr}(p=0.030)$ were significantly higher in SKR, whereas Arg digestibility was significantly lower ( $p=0.021)$ compared with that from MUL. Among NEAAs in WM, the digestibility of Ala $(p=0.014)$, Ser $(p=0.010)$ and $\operatorname{Asp}(p=0.034)$ was significantly greater, whereas Tyr digestibility was significantly lower $(p=0.030)$ in MUL compared with that from SKR

Table 5. Amino acid profile of indigenous energy sources of different origins commonly used in tilapia fish feed.

\begin{tabular}{|c|c|c|c|c|c|c|c|c|}
\hline \multirow{2}{*}{ Item } & \multicolumn{4}{|c|}{ Wheat } & \multicolumn{4}{|c|}{ Wheat middling } \\
\hline & MUL & SKR & SEM & $P$-value & MUL & SKR & SEM & $P$-value \\
\hline \multicolumn{9}{|l|}{ Essential AA } \\
\hline Arginine & 4.3 & 4.7 & 0.1 & 0.031 & 6.1 & 5.8 & 0.1 & 0.027 \\
\hline Isoleucine & 3.1 & 3.2 & 0.2 & 0.44 & 3.0 & 2.6 & 0.2 & 0.32 \\
\hline Leucine & 6.2 & 6.0 & 0.2 & 0.39 & 5.8 & 5.5 & 0.2 & 0.41 \\
\hline Lysine & 2.7 & 3.1 & 0.1 & 0.021 & 3.7 & 3.5 & 0.2 & 0.56 \\
\hline Histidine & 2.0 & 1.9 & 0.2 & 0.61 & 2.2 & 1.9 & 0.1 & 0.033 \\
\hline Methionine & 1.5 & 1.4 & 0.1 & 0.53 & 1.2 & 1.1 & 0.2 & 0.62 \\
\hline Phenylalanine & 4.3 & 4.0 & 0.2 & 0.24 & 3.2 & 3.0 & 0.2 & 0.47 \\
\hline Threonine & 2.7 & 2.8 & 0.1 & 0.45 & 3.1 & 2.9 & 0.1 & 0.32 \\
\hline Valine & 4.0 & 3.9 & 0.1 & 0.38 & 4.2 & 3.8 & 0.1 & 0.02 \\
\hline \multicolumn{9}{|c|}{ Nonessential AA } \\
\hline Glycine & 3.5 & 3.3 & 0.1 & 0.26 & 4.5 & 4.0 & 0.2 & 0.017 \\
\hline Alanine & 3.2 & 3.0 & 0.2 & 0.71 & 4.1 & 3.8 & 0.2 & 0.42 \\
\hline Tyrosine & 2.4 & 2.3 & 0.2 & 0.85 & 2.3 & 2.1 & 0.1 & 0.47 \\
\hline Serine & 4.4 & 4.1 & 0.1 & 0.04 & 4.0 & 3.6 & 0.1 & 0.036 \\
\hline Cysteine & 1.9 & 2.3 & 0.1 & 0.015 & 1.8 & 1.7 & 0.2 & 0.72 \\
\hline Glutamic acid & 25.6 & 26.3 & 0.2 & 0.030 & 17.8 & 16.9 & 0.2 & 0.01 \\
\hline Aspartic acid & 4.8 & 5.6 & 0.1 & 0.012 & 6.2 & 6.0 & 0.2 & 0.76 \\
\hline
\end{tabular}

Results described as means of triple observation. Essential AA: essential amino acids. Nonessential AA: non-essential amino acids. MUL: Multan. SKR: Sukkur. SEM: standard error of mean.

Table 6. Apparent digestibility (\%) of energy, crude protein and Amino acid indices of the indigenous energy sources of different origins in tilapia fish.

\begin{tabular}{|c|c|c|c|c|c|c|c|c|}
\hline \multirow{2}{*}{ Item $^{1}$} & \multicolumn{4}{|c|}{ Wheat } & \multicolumn{4}{|c|}{ Wheat Middling } \\
\hline & MUL & SKR & SEM & $P$-value & MUL & SKR & SEM & $P$-value \\
\hline Energy & 68.9 & 67.2 & 1.8 & 0.45 & 65.7 & 67.2 & 1.4 & 0.620 \\
\hline $\mathrm{CP}$ & 94.1 & 93.4 & 1.3 & 0.38 & 86.4 & 83.1 & 1.2 & 0.031 \\
\hline \multicolumn{9}{|l|}{ Essential AA } \\
\hline Arginine & 89.1 & 86.7 & 1.2 & 0.86 & 88.9 & 85.7 & 1.2 & 0.02 \\
\hline Isoleucine & 94.2 & 95.4 & 1.5 & 0.35 & 82.8 & 84.7 & 1.5 & 0.62 \\
\hline Leucine & 96.5 & 96.2 & 1.3 & 0.71 & 84.3 & 82.1 & 1.4 & 0.81 \\
\hline Lysine & 93.4 & 91.8 & 1.1 & 0.033 & 85.7 & 84.3 & 1.5 & 0.93 \\
\hline Histidine & 94.8 & 93.9 & 1.5 & 0.45 & 86.4 & 87.5 & 1.2 & 0.64 \\
\hline Methionine & 96.2 & 95.7 & 1.8 & 0.62 & 84.0 & 83.5 & 0.9 & 0.73 \\
\hline Phenylalanine & 95.2 & 94.8 & 1.4 & 0.51 & 81.3 & 83.8 & 1.4 & 0.80 \\
\hline Threonine & 93.4 & 90.7 & 1.2 & 0.010 & 76.8 & 80.2 & 1.3 & 0.030 \\
\hline Valine & 93.4 & 95.6 & 1.3 & 0.47 & 78.2 & 83.1 & 1.5 & 0.01 \\
\hline \multicolumn{9}{|c|}{ Nonessential AA } \\
\hline Glycine & 97.2 & 96.8 & 1.4 & 0.56 & 84.1 & 82.2 & 1.3 & 0.671 \\
\hline Alanine & 96.4 & 97.2 & 1.7 & 0.81 & 81.8 & 78.2 & 1.6 & 0.014 \\
\hline Tyrosine & 94.3 & 95.1 & 1.5 & 0.62 & 80.2 & 83.1 & 1.0 & 0.021 \\
\hline Serine & 95.7 & 96.5 & 1.6 & 0.83 & 85.3 & 82.1 & 0.9 & 0.012 \\
\hline Cysteine & 94.5 & 96.8 & 1.2 & 0.67 & 80.7 & 79.2 & 1.2 & 0.871 \\
\hline Glutamic acid & 97.2 & 95.1 & 1.4 & 0.54 & 90.2 & 89.7 & 1.4 & 0.071 \\
\hline Aspartic acid & 96.8 & 93.1 & 1.7 & 0.04 & 84.3 & 81.2 & 1.1 & 0.034 \\
\hline
\end{tabular}

${ }^{1} \mathrm{CP}$ : Crude protein. AA: Amino acids. Results described as means of triple observation. Essential AA: essential amino acids. Nonessential AA: non-essential amino acids. MUL: Multan. SKR: Sukkur. SEM: standard error of mean. 


\subsection{Aggregate amino acid contents of indigenous protein sources}

Table 7 represents the aggregate amino acid contents of commonly used indigenous protein sources (CM and RSM) of different origin. Among EAAs in CM from MUL, contents of $\operatorname{Arg}(p=0.031)$ and Phe $(p=0.035)$ were significantly higher, whereas Ile $(p=0.041)$ was significantly lower compared with that from SKR. Among NEAAs of CM, Gly $(p=0.031)$ and $\operatorname{Ser}(p=0.021)$ contents were statistically higher in SKR than that from MUL. Contents of all other AAs remained unaffected by origin. Likewise, in RSM, Met $(p=0.022)$ and valine $(p=0.031)$ contents were significantly higher among EAAs in SKR than that from MUL. Among NEAAs, Glu $(p=0.021)$ content was significantly higher in RSM from MUL, whereas $\operatorname{Ser}(p=0.010)$ was significantly lower compared with that from SKR.

\subsection{Digestible CP and AA contents of indigenous protein sources}

Apparent digestibility coefficients of $\mathrm{CP}$ and AAs of indigenous protein sources (CM and RSM) are presented in Table 8. There was non-significant effect of origin on digestibility of essential and non-essential AAs of CM

Table 7. Amino acid profile of the indigenous protein sources of different origins commonly used in tilapia fish feed.

\begin{tabular}{|c|c|c|c|c|c|c|c|c|}
\hline \multirow{2}{*}{ Item } & \multicolumn{4}{|c|}{ Canola Meal } & \multicolumn{4}{|c|}{ Rapeseed Meal } \\
\hline & MUL & SKR & SEM & $P$-value & MUL & SKR & SEM & $P$-value \\
\hline \multicolumn{9}{|l|}{ Essential AA } \\
\hline Arginine & 6.8 & 6.4 & 0.1 & 0.031 & 6.1 & 5.6 & 0.2 & 0.67 \\
\hline Histidine & 2.8 & 2.6 & 0.2 & 0.68 & 2.5 & 2.8 & 0.2 & 0.53 \\
\hline Isoleucine & 4.3 & 4.8 & 0.1 & 0.041 & 3.8 & 3.2 & 0.3 & 0.49 \\
\hline Leucine & 6.9 & 7.1 & 0.2 & 0.52 & 6.5 & 6.1 & 0.1 & 0.83 \\
\hline Lysine & 5.4 & 5.2 & 0.2 & 0.81 & 5.3 & 6.1 & 0.2 & 0.59 \\
\hline Methionine & 2.4 & 2.5 & 0.1 & 0.75 & 1.98 & 2.21 & 0.1 & 0.022 \\
\hline Phenylalanine & 5.8 & 5.2 & 0.1 & 0.035 & 5.6 & 6.2 & 0.1 & 0.63 \\
\hline Threonine & 4.6 & 4.4 & 0.2 & 0.63 & 3.9 & 4.2 & 0.2 & 0.49 \\
\hline Valine & 5.2 & 5.0 & 0.2 & 0.51 & 4.7 & 5.3 & 0.1 & 0.031 \\
\hline \multicolumn{9}{|c|}{ Nonessential AA } \\
\hline Alanine & 4.10 & 3.98 & 0.2 & 0.62 & 4.2 & 3.8 & 0.3 & 0.43 \\
\hline Aspartate & 3.21 & 3.10 & 0.1 & 0.73 & 2.1 & 1.9 & 0.1 & 0.31 \\
\hline Cysteine & 2.43 & 2.48 & 0.2 & 0.81 & 2.0 & 2.3 & 0.2 & 0.67 \\
\hline Glycine & 4.51 & 4.67 & 0.1 & 0.031 & 4.9 & 5.2 & 0.2 & 0.61 \\
\hline Glutamic acid & 6.42 & 6.18 & 0.3 & 0.49 & 16.5 & 14.3 & 0.3 & 0.021 \\
\hline Serine & 4.02 & 4.23 & 0.1 & 0.021 & 4.1 & 4.8 & 0.2 & 0.010 \\
\hline
\end{tabular}

Results described as means $\pm S E$ of triple observation. Essential AA: essential amino acids. Nonessential AA: non-essential amino acids. MUL: Multan. SKR: Sukkur. SEM: standard error of mean.

Table 8. Apparent digestibility (\%) of crude protein and amino acids of indigenous protein sources from different origin in tilapia fish.

\begin{tabular}{|c|c|c|c|c|c|c|c|c|}
\hline \multirow{2}{*}{ Item } & \multicolumn{4}{|c|}{ Canola Meal } & \multicolumn{4}{|c|}{ Rapeseed Meal } \\
\hline & MUL & SKR & SEM & $P$-value & MUL & SKR & SEM & $P$-value \\
\hline $\mathrm{CP}$ & 64.3 & 66.1 & 1.5 & 0.62 & 61.3 & 62.8 & 1.3 & 0.65 \\
\hline \multicolumn{9}{|l|}{ Essential AA } \\
\hline Arginine & 90.1 & 91.5 & 1.8 & 0.83 & 89.5 & 87.2 & 1.8 & 0.73 \\
\hline Histidine & 90.4 & 88.4 & 2.1 & 0.89 & 88.3 & 87.8 & 1.6 & 0.81 \\
\hline Isoleucine & 82.3 & 83.1 & 1.3 & 0.54 & 79.4 & 77.9 & 2.3 & 0.62 \\
\hline Leucine & 85.4 & 85.0 & 1.1 & 0.67 & 84.3 & 80.1 & 1.2 & 0.021 \\
\hline Lysine & 84.3 & 83.7 & 1.2 & 0.59 & 87.5 & 85.4 & 2.4 & 0.43 \\
\hline Methionine & 88.4 & 88.0 & 0.9 & 0.72 & 84.1 & 83.2 & 2.0 & 0.59 \\
\hline Phenylalanine & 86.1 & 85.9 & 1.8 & 0.91 & 80.3 & 77.9 & 1.7 & 0.63 \\
\hline Threonine & 85.7 & 85.2 & 2.1 & 0.83 & 81.8 & 79.5 & 2.1 & 0.83 \\
\hline Valine & 81.9 & 80.8 & 1.4 & 0.79 & 78.9 & 76.4 & 1.3 & 0.71 \\
\hline \multicolumn{9}{|c|}{ Nonessential AA } \\
\hline Alanine & 85.4 & 85.1 & 1.6 & 0.62 & 83.4 & 82.4 & 2.4 & 0.65 \\
\hline Aspartate & 80.6 & 78.9 & 2.3 & 0.73 & 82.1 & 80.7 & 2.1 & 0.39 \\
\hline Cysteine & 77.8 & 76.9 & 1.8 & 0.77 & 72.3 & 70.2 & 1.5 & 0.43 \\
\hline Glycine & 83.1 & 82.8 & 2.7 & 0.81 & 80.1 & 76.1 & 1.3 & 0.023 \\
\hline Glutamic acid & 90.7 & 90.1 & 2.0 & 0.92 & 88.5 & 80.7 & 2.3 & 0.015 \\
\hline Serine & 84.3 & 84.0 & 1.8 & 0.75 & 82.7 & 80.7 & 1.8 & 0.72 \\
\hline
\end{tabular}

Results described as means $\pm S E$ of triple observation. Essential AA: essential amino acids. Nonessential AA: non-essential amino acids. MUL: Multan. SKR: Sukkur. SEM: standard error of mean. 
from MUL and SKR. Significant increase, however, was observed in digestibility of Leu $(p=0.021)$, Gly ( $p=0.023)$ and Glu $(p=0.015)$ in MUL RSM compared with SKR. Digestibility of all other AAs were not affected by origin $(p>0.05)$.

\section{Discussion}

\subsection{Proximate analysis}

Proximate composition of the evaluated WM is within the range reported in literature (Cromwell et al., 2000). Variations in CP and ash of W and WM from two different origins may be correlated with variety, agronomic characteristics, topographical positions and environmental conditions during crop development, harvesting conditions and processing of the seeds (Daun et al., 2011). Similarly, proximate composition of $\mathrm{CM}$ was in close agreement with values described in the literature (Selle and Ravindran, 2007; Rogiewicz et al., 2012). Significant discrepancies were, however, found between CM from different origins for their chemical constituents. In agreement with published data (Nyirenda et al., 1987), season and variety affects CP, $\mathrm{CF}$, starch (energy) and ash contents in grains. The higher $\mathrm{CP}$ and energy contents in SKR samples compared with MUL samples, may be correlated with variety, different geographical locations, environmental conditions (Newkirk, 2009; Daun et al., 2011), season and site of cultivation (Conan et al., 1992; Metayer et al., 1993).

\subsection{Contents and apparent digestibility of crude protein and amino acids}

The evaluated aggregate AA contents of indigenous $\mathrm{W}$ were within range reported in literature (Abdel-Aal and Hucl, 2002; Ling et al., 2008). In the review by McNab (1996), it was reported that fertilizer application increases the total AA contents in wheat, which may be related to higher AAs contents in SKR sample. The CP digestibility of $\mathrm{W}$ was in close relation with the findings stated by Cheng and Hardy (2002). Digestibility of EAAs (Lys and Thr) of MUL W was observed to be greater than those from SKR. The digestibility of Lys was lowest despite a markedly high CP and TAA digestibility in wheat samples from SKR. This low total Lys content indicates that some of Lys and other AA may have been reduced because of grains drying process (Widyaratne and Zijlstra, 2008).

Variations in amino acids composition of WM samples may be attributed with variety, agronomic conditions, locations and environmental impact during crop development (Daun et al., 2011). According to Furuya et al. (2001) and Adewole et al. (2017), high CF and non-starch polysaccharides contents reduce time of contact between enzyme and substrate, hence reducing the digestibility that may be related to low digestibility values for WM compared with $\mathrm{W}$.

In the present study, AA contents of indigenous CM samples were within range described in the literature (Guimarães et al., 2008). The AA digestibility of CM showed no difference regarding their origin. In addition, according to published literature, average AA digestibility of CM was high (Forster et al., 1999), with Arg being the most digestible AA, whereas Cys being the poorer one. These higher digestibility values could be due to reduced erucic acid and glucosinolates contents in CM by applying heat treatment after oil extraction by hexane (Newkirk, 2002; Drew et al., 2007).

The AAs composition of RSM was in line with the findings stated in literature (Kasprzak et al., 2017; Ullah et al., 2017). Reduced AAs contents of RSM from MUL could be due to varietal or seasonal differences. Application of high temperature during the processing of rapeseeds to extract oil could also be a reason for lower AAs contents in RSM (González-Vega et al., 2011). In addition, existence of anti-nutritional factors (erucic acid and glucosinolates) in RSM may result in reduced digestibility of CP (Zhou et al., 2004) and AAs (Khajali and Slominski, 2012). The greater hemicellulose, cellulose and pectin in rapeseed hulls may bind with AA released during protein digestion and thereby decrease the AA absorption in the small intestine (Bjergegaard et al., 1991).

\section{Conclusions}

The findings of the current study showed various nutritional differences in the ingredients from different origins. These variations were, however, small in most of the nutrients. The variations were also observed in the digestibility values of different nutrients due to their origin. This generated database can be helpful for nutritionist formulating diets by using indigenous ingredients, for Nile tilapia and other fish species.

\section{Acknowledgements}

The authors highly acknowledge the financial support of SUNAR Pakistan, with the financial assistance of Australian Government, for the execution of fish trials.

\section{References}

ABDEL-AAL, E.S.M. and HUCL, P., 2002. Amino acid composition and in vitro protein digestibility of selected ancient wheats and their end products. Journal of Food Composition and Analysis, vol. 15, no. 6, pp. 737-747. http://dx.doi.org/10.1006/ jfca.2002.1094.

ADEWOLE, D.I., ROGIEWICZ, A., DYCK, B. and SLOMINSKI, B.A., 2017. Effects of canola meal source on the standardized ileal digestible amino acids and apparent metabolisable energy contents for broiler chickens. Poultry Science, vol. 96, no. 12, pp. 4298-4306. http://dx.doi.org/10.3382/ps/pex245. PMid:29053814.

ASSOCIATION OF OFFICIAL ANALYTICAL CHEMISTS AOAC, 2000. Official methods of analysis. Gaithersburg: AOAC.

BJERGEGAARD, C., EGGUM, B., JENSEN, S. and SØRENSEN, H., 1991. Dietary fibers in oilseed rape: physiological and antinutritional effects in rats of isolated IDF and SDF added to a standard diet. Journal of Animal Physiology and Animal Nutrition, vol. 66, no. 1-5, pp. 69-79. http://dx.doi. org/10.1111/j.1439-0396.1991.tb00280.x. 
CHENG, Z. and HARDY, R., 2002. Effect of microbial phytase on apparent nutrient digestibility of barley, canola meal, wheat and wheat middling, measured in vivo using rainbow trout (Oncorhynchus mykiss). Aquaculture Nutrition, vol. 8, no. 4, pp. 271-277. http://dx.doi.org/10.1046/j.1365-2095.2002.00219.x.

CHO, C.Y. and SLINGER, S.J., 1979. Apparent digestibility measurement in feedstuff for rainbow trout. In J.E. HALVER and K. TIEWS, ed. Finfish nutrition and fishfood technology. Berlin, Germany: Heenemann GmbH, vol. 2, pp. 239-294.

CONAN, L., METAYER, J.P., LESSIRE, M. and WIDIEZ, J.L., 1992. Metabolisable energy content of cereal grains in poultry. Recent yearly surveys in France. Productions Animales, vol. 5, no. 5 , pp. 329-338.

CROMWELL, G.L., CLINE, T.R., CRENSHAW, J.D., CRENSHAW, T.D., EASTER, R.A., EWAN, R.C., HAMILTON, C.R., HILL, G.M., LEWIS, A.J., MAHAN, D.C., NELSSEN, J.L., PETTIGREW, J.E., VEUM, T.L. and YEN, J.T., 2000. Variability among sources and laboratories in analyses of wheat middling. Journal of Animal Science, vol. 78, no. 10, pp. 26522658. http://dx.doi.org/10.2527/2000.78102652x. PMid:11048931.

DAUN, J.K., ESKIN, N. and HICKLING, D., 2011. Canola: chemistry, production, processing, and utilization. Urbana, IL: AOCS Press.

DREW, M.D., BORGESON, T.L. and THIESSEN, D.L., 2007. A review of processing of feed ingredients to enhance diet digestibility in finfish. Animal Feed Science and Technology, vol. 138, no. 2, pp. 118-136. http://dx.doi.org/10.1016/j.anifeedsci.2007.06.019.

FAIRBAIRN, S.L., PATIENCE, J.F., CLASSEN, H.L. and ZIJLSTRA, R.T., 1999. The energy content of barley fed to growing pigs: characterizing the nature of its variability and developing prediction equations for its estimation. Journal of Animal Science, vol. 77, no. 6, pp. 1502-1512. http://dx.doi. org/10.2527/1999.7761502x. PMid:10375227.

FOOD AND AGRICULTURE ORGANIZATION - FAO, 2017. FAO Aquaculture Newsletter, April 2017. no. 56. Rome, Italy: FAO, 2 p.

FORSTER, I., HIGGS, D.A., DOSANJH, B.S., ROWSHANDELI, M. and PARR, J., 1999. Potential for dietary phytase to improve the nutritive value of canola protein concentrate and decrease phosphorus output in rainbow trout (Oncorhynchus mykiss) held in $11^{\circ} \mathrm{C}$ fresh water. Aquaculture, vol. 179, no. 1-1, pp. 109-125.

FURUYA, W.M., PEZZATO, L.E., PEZZATO, A.C., BARROS, M.M. and MIRANDA, C.E., 2001. Digestibility coefficients and digestible amino acids values of some ingredients for Nile tilapia (Oreochromis niloticus). Revista Brasileira de Zootecnia, vol. 30, no. 4, pp. 1143-1149. http://dx.doi.org/10.1590/S151635982001000500002 .

GONZÁLEZ-VEGA, J.C., KIM, B.G., HTOO, J.K., LEMME, A. and STEIN, H.H., 2011. Amino acid digestibility in heated soybean meal fed to growing pigs. Journal of Animal Science, vol. 89, no. 11, pp. 3617-3625. http://dx.doi.org/10.2527/jas.20103465. PMid:21742940.

GUIMARÃES, I.G., PEZZATO, L.E., BARROS, M.M. and TACHIBANA, L., 2008. Nutrient digestibility of cereal grain products and by-products in extruded diets for Nile tilapia. Journal of the World Aquaculture Society, vol. 39, no. 6, pp. 781-789. http://dx.doi.org/10.1111/j.1749-7345.2008.00214.x.

KASPRZAK, M.M., HOUDIJK, J.G.M., OLUKOSI, O.A., APPLEYARD, H., KIGHTLEY, S.P.J., CARRE, P. and WISEMAN, J., 2017. The influence of oil extraction process of different rapeseed varieties on the ileal digestibility of crude protein and amino acids in broiler chickens. Animal Feed Science and Technology, vol. 227, pp. 68-74. http://dx.doi.org/10.1016/j. anifeedsci.2017.03.009.

KHAJALI, F. and SLOMINSKI, B.A., 2012. Factors that affect the nutritive value of canola meal for poultry. Poultry Science, vol. 91, no. 10, pp. 2564-2575. http://dx.doi.org/10.3382/ps.201202332. PMid:22991543

LING, J.X., CHUN, T., ZHI, H. and DONG, Z., 2008. Protein content and amino acid composition in grains of wheat-related species. Agricultural Sciences in China, vol. 7, no. 3, pp. 272-279. http://dx.doi.org/10.1016/S1671-2927(08)60066-8.

LIU, H., WU, X., ZHAO, W., XUE, M., GUO, L., ZHENG, Y. and YU, Y., 2009. Nutrients apparent digestibility coefficients of selected protein sources for juvenile Siberian sturgeon (Acipenser baerii Brandt), compared by two chromic oxide analyses methods. Aquaculture Nutrition, vol. 15, no. 6, pp. 650-656. http://dx.doi. org/10.1111/j.1365-2095.2008.00634.x.

MAISON, T. and STEIN, H.H., 2014. Digestibility by growing pigs of amino acids in canola meal from North America and 00-rapeseed meal and 00-rapeseed expellers from Europe. Journal of Animal Science, vol. 92, no. 8, pp. 3502-3514. http://dx.doi. org/10.2527/jas.2014-7748. PMid:24987076.

MARKOVIĆ, G., MADIĆ, M., BOKAN, N. and ĆIRKOVIĆ, M., 2016. Alternative cereals in Carp (Cyprinus carpio L.) Nutrition. Contemporary Agriculture, vol. 65, no. 1-2, pp. 23-27. http://dx.doi.org/10.1515/contagri-2016-0004.

MCNAB, J., 1996. Factors affecting the energy value of wheat for poultry. World's Poultry Science Journal, vol. 52, no. 1, pp. 69-73. http://dx.doi.org/10.1079/WPS19960008.

METAYER, J.P., GROSJEAN, F. and CASTAING, J., 1993. Study of variability in French cereals. Animal Feed Science and Technology, vol. 43, no. 1-2, pp. 87-108. http://dx.doi. org/10.1016/0377-8401(93)90145-A.

NATIONALAGRICULTURAL RESEARCH COUNCIL - NARC, 2017 [viewed 12 March 2017]. Maize, Millet and Sorghum Research Program [online]. Islamabad: NARC. Available from: http://www.parc.gov.pk/index.php/en/csi/137-narc/crop-sciencesinstitue/715-maize-millet-sorghum-research-program

NEWKIRK, R., 2009. Canola meal feed industry guide. 4th ed. Winnipeg: Canola Council.

NEWKIRK, R.W., 2002. The effects of processing on the nutritional value of Canola Meal for broiler chickens. Saskatoon, SK, Canada: University of Saskatchewan, Ph.D. Thesis.

NYIRENDA, D.B.G., VOHRA, P. and INGEBRETSON, K.H., 1987. Nutritional evaluation of some varieties of sorghums (Sorghum bicolor Moench). Cereal Chemistry, vol. 64, pp. 41317.

RAVINDRAN, V. and BRYDEN, W.L., 1999. Amino acid availability in poultry-in vitro and in vivo measurements. Australian Journal of Agricultural Research, vol. 50, no. 5, pp. 889-908. http://dx.doi.org/10.1071/AR98174.

ROGIEWICZ, A., NURNBERG, L. and SLOMINSKI, B.A., 2012. The effect of prepress-solvent extraction on the chemical and nutritive composition of canola meal. In: Proceeding 24th World's Poultry Congress, 5-9 August 2012, Salvador, Brazil. World's Poultry Congress: Netherlands.

SAS INSTITUTE, 1985. SAS user's guide: statistics, version 9.2. Cary, NC, USA: SAS Institute, Inc. 
SCOTT, K., 1978. Cause and control of losses of chromium during nitric, perchloric acid oxidation of aquatic sediments. Analyst, vol. 103, no. 1228, pp. 754-758. http://dx.doi.org/10.1039/ an9780300754.

SELLE, P.H. and RAVINDRAN, V., 2007. Microbial phytase in poultry nutrition. Animal Feed Science and Technology, vol. 135, no. 1-2, pp. 1-41. http://dx.doi.org/10.1016/j.anifeedsci.2006.06.010.

TOGHYANI, M., RODGERS, N., IJI, P.A. and SWICK, R.A., 2015. Standardized ileal amino acid digestibility of expeller extracted canola meal subjected to different processing conditions for starter and grower broiler chickens. Poultry Science, vol. 94, no. 5, pp. 992-1002. http://dx.doi.org/10.3382/ps/pev047. PMid:25784766.

ULLAH, Z., REHMAN, Z.U., YIN, Y., STEIN, H.H., HAYAT, Z., AHMED, G., NISA, M.U., AKHTAR, M. and SARWAR,
M., 2017. Comparative ileal digestibility of amino acids in 00-rapeseed meal and rapeseed meal fed to growing male broilers. Poultry Science, vol. 96, no. 8, pp. 2736-2742. http:// dx.doi.org/10.3382/ps/pex083. PMid:28453657.

WIDYARATNE, G.P. and ZIJLSTRA, R.T., 2008. Nutritional value of wheat and corn distiller's dried grain with solubles: digestibility and digestible contents of energy, amino acids and phosphorus, nutrient excretion and growth performance of growerfinisher pigs. Canadian Journal of Animal Science, vol. 87, no. 1, pp. 103-106. http://dx.doi.org/10.4141/A05-070.

ZHOU, Q.C., TAN, B.P., MAI, K.S. and LIU, Y.J., 2004. Apparent digestibility of selected feed ingredients for juvenile cobia Rachycentron canadum. Aquaculture, vol. 241, no. 1-4, pp. 441-451. http://dx.doi.org/10.1016/j.aquaculture.2004.08.044. 